\title{
Effect of antipyrine on the gastric emptying of liquid in rats
}

A.C.F. Soares ${ }^{1}$,

A.M. Vinagre ${ }^{2}$ and E.F. Collares ${ }^{1,2,3}$

\author{
${ }^{1}$ Departamento de Pediatria, ${ }^{2}$ Núcleo de Medicina and Cirurgia Experimental, \\ ${ }^{3}$ Centro de Investigação em Pediatria, Faculdade de Ciências Médicas, \\ Universidade Estadual de Campinas, Campinas, SP, Brasil
}

\begin{abstract}
Correspondence
A.C.F. Soares

Departamento de Pediatria

Faculdade de Ciências Médicas UNICAMP

13083-970 Campinas, SP

Brasil

Fax: +55-19-3788-7322

E-mail: anafontenele@uol.com.br

Publication supported by FAPESP.

$\ldots \ldots \ldots \ldots \ldots \ldots$
\end{abstract}

Received September 27, 2005

Accepted July 27, 2006

\begin{abstract}
Antipyrine (At) and dipyrone (Dp) delay gastric emptying (GE) in rats. The objective of the present study was to assess the effects of intravenous ( $i v)$ and intracerebroventricular ( $i c v)$ administration of At and $\mathrm{Dp}$ on the GE of liquid by rats. GE was assessed in male Wistar rats (5-10 in each group) 10 min after the $i c v$ or $i v$ drug injection by measuring percent gastric retention $(\% \mathrm{GR})$ of a saline test meal labeled with phenol red 10 min after administration by gavage. The At iv group was significantly higher $(64.4 \pm 2.6 \%)$ compared to control $(33.4 \pm 1.5 \%)$ but did not differ from the Dp group $(54.3 \pm 3.8 \%)$. After $i c v$ administration of At, \%GR $(34.2 \pm 2 \%)$ did not differ from control $(32.6 \pm 1.9 \%)$, but was significantly higher after Dp $(54.5 \pm$ $2.3 \%$ ). Subdiaphragmatic vagotomy significantly reduced \%GR in the At group $(30.2 \pm 0.7 \%)$ compared to the sham group, but was significantly higher than in the controls $(23.0 \pm 0.5 \%)$. In the animals treated with At $i v$, baclofen significantly reduced \%GR $(28.3 \pm 2.4 \%)$ compared to vehicle-treated animals $(55.2 \pm 3.2 \%)$. The same occurred in the animals treated $i v$ with vehicle and $i c v$ with baclofen. Although vagotomy and baclofen reduced \%GR per se, the reduction was twice more marked in the animals treated with At. The results suggest that At administered $i v$, but not $i c v$, delays GE of liquid in rats with the participation, at least in part, of the vagus nerve and that this phenomenon is blocked by the activation of $\mathrm{GABA}_{\mathrm{B}}$ receptors in the central nervous system.
\end{abstract}

\section{Introduction}

Gastric emptying (GE) is the process of the transfer of the gastric content to the small intestine as the result of the motor activity of the stomach, pylorus and duodenum under control of inhibitory and stimulatory mechanisms (1).

Non-steroidal anti-inflammatory drugs are among the most frequently prescribed
Key words

- Gastric emptying

- Dipyrone

- Antipyrine

- $\mathrm{GABA}_{\mathrm{B}}$ receptors

- Vagus nerve drugs in the world and have been extensively studied because of their gastrointestinal toxicity. Among the effects of these medications, changes in GE have been reported to be induced by aspirin, acetaminophen and indomethacin (2-6). Dipyrone (Dp), a phenylpyrazolone derivative mainly used for its antipyretic and analgesic properties, causes delayed GE in rats when administered at high doses (7). This effect was confirmed 
using a dose of $80 \mathrm{mg} / \mathrm{kg}(240 \mu \mathrm{mol} / \mathrm{kg})$ administered intravenously (iv) and saline solution as a test meal (8). A recent study in which Dp was administered $i v$ and intracerebroventricularly (icv) to rats has suggested that this effect may be due to the action of the drug on the central nervous system (CNS), with the participation of the paraventricular nucleus and of the vagus nerve (9). Additional observations have demonstrated that this phenomenon is blocked by icv administration of baclofen (bac), a $\mathrm{GABA}_{\mathrm{B}}$ receptor agonist (10).

Takanaka et al. (11), in a study on the effect of antipyrine (At, phenazone), another phenylpyrazolone derivative, on the GE of rats, observed delayed GE after its administration. However, the site of action and the mechanisms involved in this phenomenon are unknown.

The objective of the present study was to assess the effect of At on the GE of rats, using saline solution as a test meal. The following procedures were carried out: 1) comparative studies with Dp using equivalent doses administered iv $(240 \mu \mathrm{mol} / \mathrm{kg})$ and icv (4 $\mu \mathrm{mol} /$ animal); 2) study of the dose-response effect and time-response effect of At administered $i v$; 3) study of the effect of subdiaphragmatic vagotomy $(\mathrm{VgX})$ on the $i v$ administration of the drug; 4) study of the effect of $i c v$ administration of bac on the $i v$ administration of the drug.

\section{Material and Methods}

The study was conducted on 8-week-old male Wistar rats weighing 250-300 g, adapted to laboratory conditions for 4 weeks and receiving water and food ad libitum. The experimental protocols used in the present study followed the recommendations of the Brazilian College of Animal Experimentation (COBEA).

The drugs used, dipyrone, antipyrine, and baclofen (all from Sigma, St. Louis, MO, USA) were diluted in sterile physiological saline as a vehicle at the time of the experiments.

The GE test was carried out in animals fasted for $24 \mathrm{~h}$ but with free access to water, which was removed $30 \mathrm{~min}$ before the experiments.

For the comparative study of At and Dp injected $i v$ the animals were divided into three groups: At and Dp groups, respectively receiving $i v 45.17$ and $80 \mathrm{mg} / \mathrm{kg}$ of the drug corresponding to the dose of $240 \mu \mathrm{mol} /$ $\mathrm{kg}$, and control group $(\mathrm{C})$ receiving vehicle ( $1 \mathrm{~mL} / \mathrm{kg}$ body weight). Drugs were injected $i v$ through a tail vein and GE was assessed 10 min after administration.

For the assessment of the effect of At and Dp administered $i c v$, a cannula was implanted into the right lateral ventricle of each animal 8 days before the experiments using previously established coordinates $(9,10)$. For $i c v$ injection, $10 \mu \mathrm{L}$ saline $(\mathrm{C})$, Dp $(4 \mu \mathrm{mol}=$ $1333.2 \mu \mathrm{g})$, or At $(4 \mu \mathrm{mol}=752.8 \mu \mathrm{g})$ was used. The dose (in $\mu \mathrm{mol}$ ) and the technique employed for icv administration had been established in a previous study (9). GE was assessed $10 \mathrm{~min}$ after the end of the $i c v$ injection.

For the study of the dose-response effect, iv doses of $60(11.25 \mathrm{mg} / \mathrm{kg}), 120(22.5 \mathrm{mg} /$ $\mathrm{kg}$ ), and $240 \mu \mathrm{mol} / \mathrm{kg}(45.17 \mathrm{mg} / \mathrm{kg})$ At were used. Control animals $(\mathrm{C})$ received vehicle by the same route. GE was assessed $10 \mathrm{~min}$ after administration. For the study of the time-response effect, At or vehicle was administered $i v$ at the dose of $240 \mu \mathrm{mol} / \mathrm{kg}$ $(45.17 \mathrm{mg} / \mathrm{kg})$, and GE was assessed 10, 30, 60 , and 120 min after administration.

To assess the participation of the vagus nerve in the effect of At on GE, the rats were submitted to subdiaphragmatic section of the ventral and dorsal branches of the vagus (VgX group) 2 weeks before the experiment. The sham group consisted of rats submitted to surgery without section of the vagal branches. Each group was divided into subgroups of animals receiving vehicle (C) or At at the dose of $240 \mu \mathrm{mol} / \mathrm{kg}(45.17 \mathrm{mg} /$ 
$\mathrm{kg}) i v$. GE was assessed 10 min after administration.

To assess the action of bac on the effect of At, a solution of $2 \mu \mathrm{g}$ bac (bac2) or vehicle (bac0) was applied icv $(10 \mu \mathrm{L})$ and the animals then received a solution of At, 240 $\mu \mathrm{mol} / \mathrm{kg}$, or vehicle (C) iv. The baclofen dose and the technique employed for $i c v$ administration had been established in a previous study (10). GE was assessed $10 \mathrm{~min}$ after the end of the $i v$ injection.

In all experiments, GE was evaluated indirectly by measuring percent gastric retention (\%GR) of a saline test meal labeled with phenol red $(60 \mu \mathrm{g} / \mathrm{mL})$ in a volume of 2 $\mathrm{mL} / 100 \mathrm{~g}$ body weight administered by gavage using a standardized technique (12). The absorbance of the dye was determined with a spectrophotometer at $560 \mathrm{~nm}$. At the end of the experiment all animals were sacrificed and the brain of those submitted to $i c v$ injection was injected with $10 \mathrm{~mL} 1 \%$ Evans blue through the cannula. The brain was removed and fixed in $10 \%$ formalin for $24 \mathrm{~h}$. After fixation, coronal sections were obtained and the proper site of injection was confirmed when the dye was observed in the fourth ventricle.

\section{Statistical analysis}

Data are reported as means \pm SEM. Statistical analysis was carried out using ANOVA followed by the Tukey test when necessary. When it was not possible to use parametric tests, the Kruskal-Wallis test was used, followed by the multiple comparisons Dunn test when necessary. The level of significance was set at $\alpha=5 \%$ for all tests.

\section{Results}

The data regarding the effect of Dp and At administered $i v$ are presented in Figure 1A. The At and Dp groups presented a significantly more elevated \%GR compared to control. The At group showed higher \%GR values (mean $\pm \mathrm{SEM}=64.4 \pm 2.6 \%$ ) which, however, did not differ significantly from Dp $(54.3 \pm 3.8 \%)$. The data regarding the effect of $\mathrm{Dp}$ and At administered icv are presented in Figure 1B. There was a significant increase in \%GR in the Dp group (54.5 \pm $2.3 \%)$ compared to the $\mathrm{C}(32.6 \pm 1.9 \%)$ and At $(34.2 \pm 2 \%)$ groups, whereas the At group did not differ significantly from control.

The dose-response study (Figure 2A) showed a dose-dependent increase in \%GR in the animals treated with At $(r=0.86)$ which, however, was significant only at the dose of $240 \mu \mathrm{mol} / \mathrm{kg}(64.5 \pm 4.7 \%) \mathrm{com}$ pared to control $(37.4 \pm 1.2 \%)$. Regarding the time-response study, the At group showed a maximum effect of the drug on \%GR at 10 $\min (67.6 \pm 3 \%)$ compared to control (37.4 \pm $1.3 \%)$. A progressive reduction occurred, with the maintenance of a significant difference from control at 30 and $60 \mathrm{~min}$ which, however, no longer existed at $120 \mathrm{~min}$ (Figure 2B).

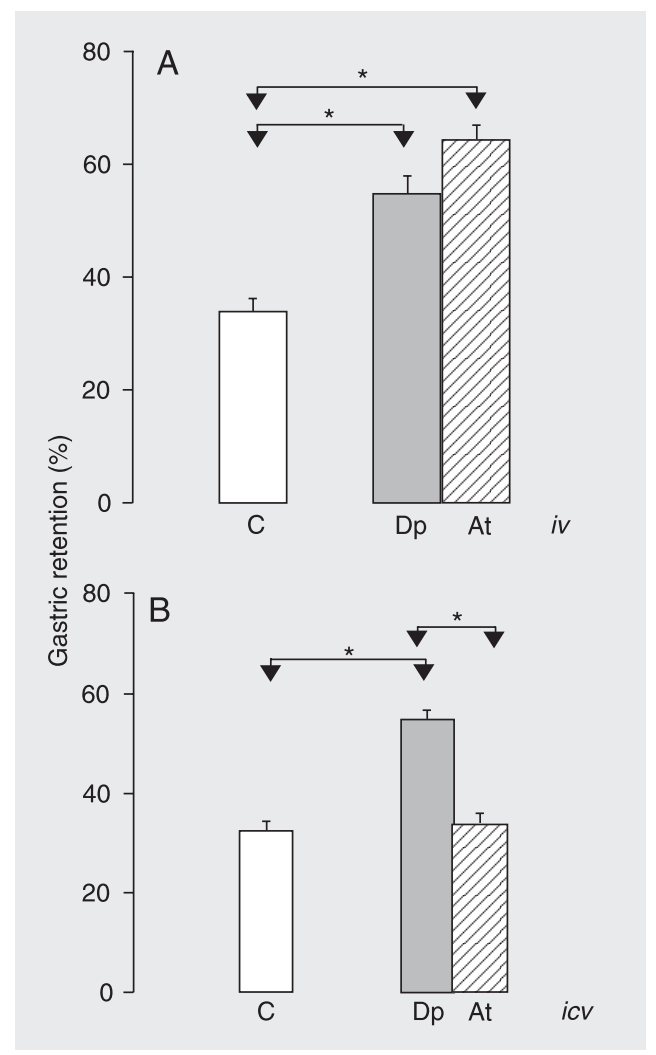

Figure 1. Gastric retention of a saline test meal $10 \mathrm{~min}$ after administration to rats by gavage. $A$, Ten minutes before the evaluation of gastric retention, the animals received intravenous (iv) vehicle (C) or $240 \mu \mathrm{mol} / \mathrm{kg}$ dipyrone (Dp; $80 \mathrm{mg} / \mathrm{kg}$ ), or 240 $\mu \mathrm{mol} / \mathrm{kg}$ antipyrine (At; 45.17 $\mathrm{mg} / \mathrm{kg}$ ). $B$, Eight days before the test, a metal cannula was implanted into the right lateral ventricle of each rat. The animals received intracerebroventricular (icv) $10 \mu \mathrm{L}$ of vehicle (C) or an equal volume of a solution containing $4 \mu \mathrm{mol}(1333.2 \mu \mathrm{g}) \mathrm{Dp}$ or $4 \mu \mathrm{mol}(752.8 \mu \mathrm{g})$ At. Gastric retention was assessed $10 \mathrm{~min}$ after the icv injections. Data are reported as means \pm SEM for 10 animals per group. ${ }^{*} \mathrm{P}<0.05$ for the comparisons indicated by the arrows (Tukey test). 
Figure 2. Gastric retention of a saline test meal 10 min after administration to rats by gavage. $A$, Ten minutes before the evaluation of gastric retention, the animals received iv vehicle $(C)$ or 60 (11.25 mg/kg), 120 (22.5 mg/ $\mathrm{kg})$ and $240 \mu \mathrm{mol} / \mathrm{kg}(45.17 \mathrm{mg} /$ $\mathrm{kg}$ ) antipyrine (At). B, Ten, 30, 60 , and $120 \mathrm{~min}$ before the evaluation of gastric retention the animals received iv vehicle (C) or $240 \mu \mathrm{mol} / \mathrm{kg}$ (45.17 mg/ kg) At. Data are reported as means \pm SEM for 5 animals per group. ${ }^{\star} P<0.05$ for the comparisons indicated by the arrows (Tukey test).

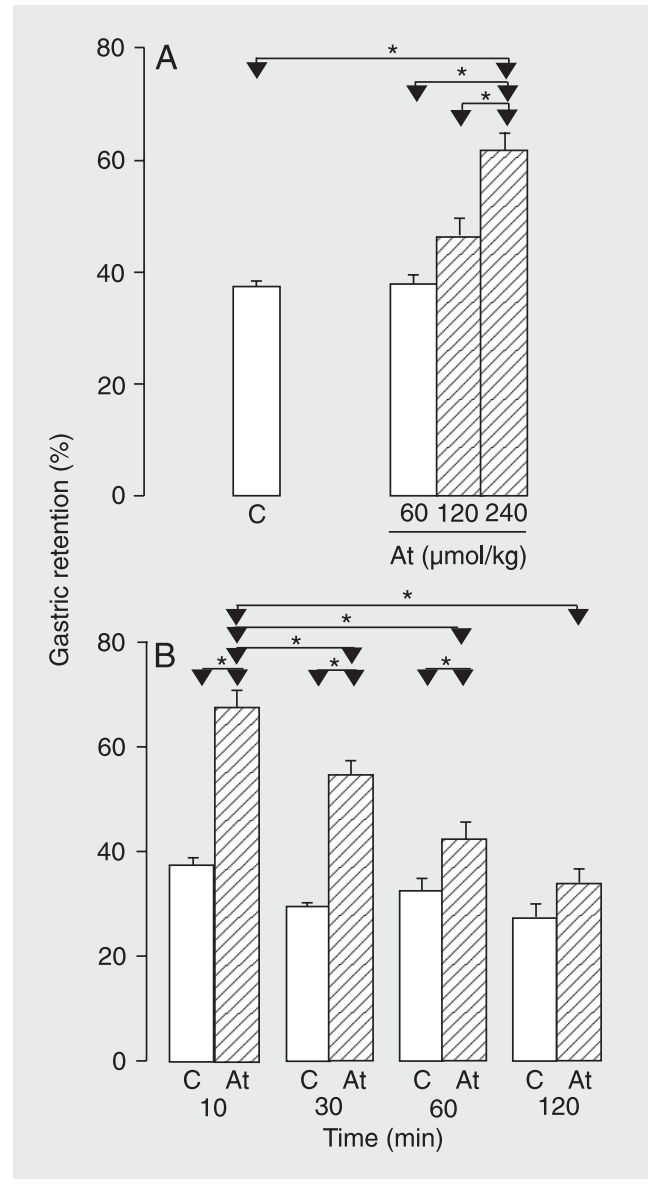

In the study of the participation of the vagus nerve (Figure 3A) the animals of the sham group which received At presented a significant increase in \%GR $(57.9 \pm 0.8 \%)$ compared to control $(29.4 \pm 0.8 \%)$. Although vagotomy reduced $\% \mathrm{GR}$ in the animals treated with At $(30.2 \pm 0.7 \%)$, the difference was significant compared to the controls receiving vehicle $(23.0 \pm 0.5 \%)$. Vagotomy significantly reduced \%GR in the animals treated with At compared to the sham group (VgXAt $v s$ shamAt) and the same phenomenon was observed among the animals that received vehicle ( $\mathrm{VgXC} v s$ shamC); however, the reduction was twice higher in the animals that received At (a 47.8\% reduction in mean \% GR) compared to control (a 23.8\% reduction in mean $\% \mathrm{GR}$ ).

The results of the action of $i c v$ baclofen on the effect of $i v$ At are presented in Figure
3B. The bac0At group presented a significantly higher \%GR $(55.2 \pm 3.2 \%)$ compared to the bac0C group $(34.0 \pm 1.8 \%)$. On the other hand, the \%GR of the bac2At group $(28.3 \pm 2.4 \%)$ did not differ significantly from control (bac2C, $25.2 \pm 3.2 \%$ ). Baclofen administered $i c v$ significantly reduced \%GR in the animals that received At $i v$ (bac2At $v s$ bac0At) and in the control groups that received saline $i v$ (bac $2 \mathrm{C} v s$ bac0C); however, the reduction was approximately twice higher in the animals receiving At (a $48.7 \%$ reduction in mean \%GR) compared to control (a $26.1 \%$ reduction in mean $\% \mathrm{GR})$.

\section{Discussion}

We observed in the present study that antipyrine administered $i v$ delayed GE of liquids in rats in a dose-dependent manner, a phenomenon that differed from the effect observed with dipyrone. First, the effect of antipyrine was more intense during the first 10 min after $i v$ administration, whereas the effect of dipyrone was approximately constant during the first hour (9). Second, when the drug was administered icv it did not change GE, indicating that it has no direct effect on the CNS, in contrast to what was observed with the administration of dipyrone. These facts suggest that the two drugs, although having a common chemical origin as phenylpyrazolone derivatives, cause delayed GE by distinct mechanisms.

After per os administration to humans, antipyrine is rapidly and fully absorbed and is then slowly metabolized, with a mean plasma clearance rate of $6 \%$ per hour (13). The hepatic isoenzymes of cytochrome P450 participate in these metabolic processes, giving origin to metabolites which are mainly eliminated through the kidneys $(14,15)$. If we assume that the observed delay in GE is due to the action of antipyrine and not of its metabolites, it is not clear why the drug, which continues to circulate and whose clearance is slow, has the most pronounced effect 
on GE 10 min after administration. Two possibilities may be proposed to explain this discrepancy: 1) The drug is inactivated or gradually metabolized at the site where it induces the delay, or 2) the mechanism that antagonizes the effect of delayed GE is able to partially counterbalance the effect of antipyrine.

Subdiaphragmatic vagotomy is known to modify the motor activity of the stomach, blocking the arrival of afferent stimuli to the tractus solitarius and of stimulating and inhibitory efferents originating from the dorsal nucleus of the vagus (16-18). In the present study, vagotomy reduced the effect on GE induced by $i v$ administration of antipyrine, suggesting the participation of vagal pathways in this phenomenon. Since this procedure did not fully abolish the effect, we may conclude that the drug acts by a mechanism that does not depend, at least in part, on the participation of the vagus nerve.

In addition, the effect of $i v$ antipyrine on GE was blocked by icv baclofen. The activation of $\mathrm{GABA}_{\mathrm{B}}$ receptors by baclofen in the CNS results in hyperpolarization of the postsynaptic membranes or in inhibition of neurotransmitter release at presynaptic nerve endings $(19,20)$. There is strong evidence that $\mathrm{GABA}$, through $\mathrm{GABA}_{\mathrm{B}}$ receptors, may participate in the control of gastric secretion and gastrointestinal motility at the level of the nucleus tractus solitarii (19,21-26). On this basis, we may speculate that the stimulation of presynaptic $\mathrm{GABA}_{B}$ receptors by baclofen, by blocking the excitation of the non-adrenergic cholinergic (inhibitory) pathway and/or the inhibition of the cholinergic (stimulatory) pathway of the vagus determined by antipyrine, may explain the results of the present study. Probably this is not the only hypothesis if we consider that vagotomy

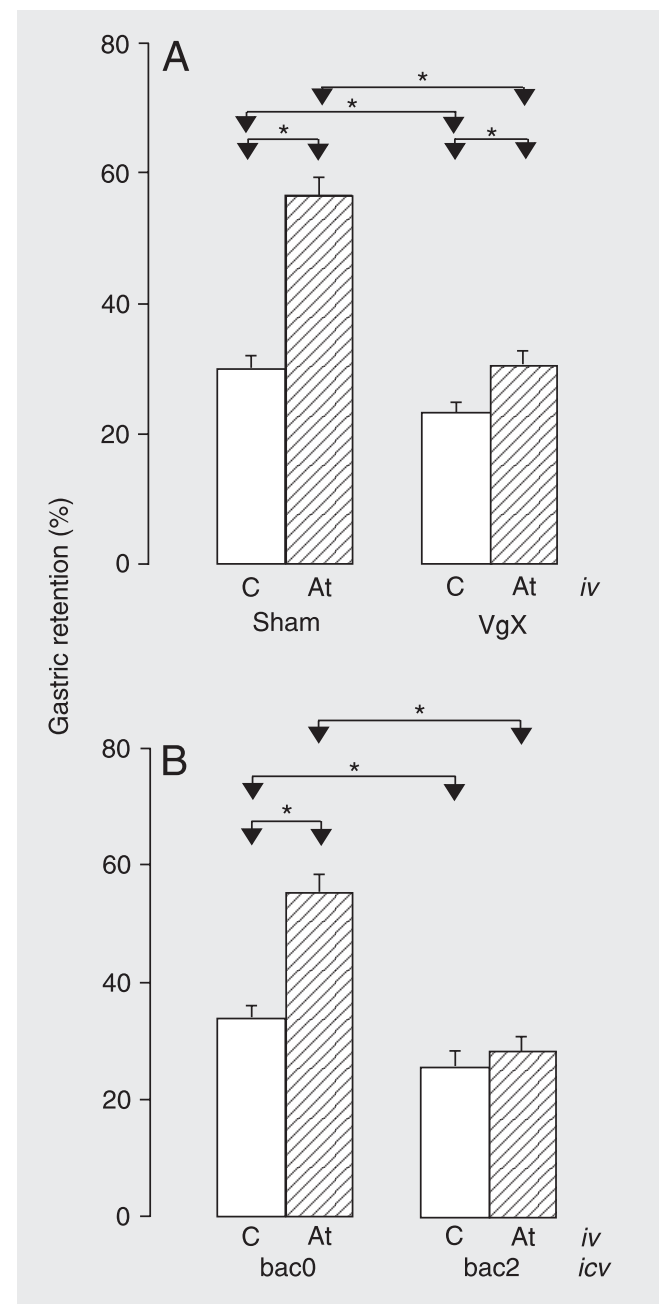

and baclofen administration in the CNS reduced \%GR per se, although the reduction was twice more marked in the animals that received antipyrine. On the basis of the present results, no other speculations would be valid here.

The present results suggest that antipyrine administered $i v$, but not $i c v$, delays GE of liquid in rats with the participation, at least in part, of the vagus nerve and that this phenomenon is blocked by the activation of $\mathrm{GABA}_{\mathrm{B}}$ receptors in the CNS.
Figure 3. Gastric retention of a saline test meal 10 min after administration to rats by gavage. $A$, Two weeks before the test the animals were submitted to sham surgery (Sham group) or to subdiaphragmatic vagotomy ( $\mathrm{VgX}$ group). Ten minutes before the evaluation of gastric retention the animals of each group received intravenous (iv) vehicle (C) or $240 \mu \mathrm{mol} / \mathrm{kg}$ $(45.17 \mathrm{mg} / \mathrm{kg})$ antipyrine (At). $B$, Eight days before the test, a metal cannula was implanted into the right lateral ventricle of each rat. The animals received an intracerebroventricular (icv) injection of $10 \mu \mathrm{L}$ vehicle (baco) or an equal volume of solution containing $2 \mu \mathrm{g}$ baclofen (bac2) injected over a period of $30 \mathrm{~s}$, followed by iv vehicle (C), or a solution of At, $240 \mu \mathrm{mol} / \mathrm{kg}$ $(45.17 \mathrm{mg} / \mathrm{kg})$. Gastric retention was assessed $10 \mathrm{~min}$ after the end of the iv injection. Data are reported as means \pm SEM for 10 animals per group. ${ }^{*} \mathrm{P}<0.05$ for the comparisons indicated by the arrows (Dunn test). 


\section{References}

1. Weisbrodt NW. Gastric emptying. In: Johnson LR (Editor), Gastrointestinal physiology. 5th edn. St. Louis: Mosby; 1997. p 33-42.

2. Hawkey CJ. Nonsteroidal anti-inflammatory drug gastropathy. Gastroenterology 2000; 119: 521-535.

3. Shea-Donohue T, Steel L, Montcalm-Mazzilli E, Dubois A. Aspirininduced changes in gastric function: role of endogenous prostaglandins and mucosal damage. Gastroenterology 1990; 98: 284-292.

4. Hessel G, Collares EF. Gastric emptying in rats with acetaminophen-induced hepatitis. Braz J Med Biol Res 1998; 31: 1133-1139.

5. Souza MH, Troncon LE, Cunha FQ, Oliveira RB. Decreased gastric tone and delayed gastric emptying precede neutrophil infiltration and mucosal lesion formation in indomethacin-induced gastric damage in rats. Braz J Med Biol Res 2003; 36: 1383-1390.

6. Vinagre AM, Collares EF. Efeito da indometacina sobre o esvaziamento gástrico de líquidos em ratos. XVIII Annual Meeting of the Federação de Sociedades de Biologia Experimental. 27-30 August 2003; Curitiba.

7. Rupp VS, Schrort HJ, Hildebrant U. Einfluss von Metamizol auf Megenetleerung und Dunndarmtransit bei der Ratte. Arzneimittelforschung 1987; 37: 1051-1053.

8. Collares EF, Vinagre AM. Efeito da dipirona sobre o esvaziamento gástrico de ratos. XIII Annual Meeting of the Federação de Sociedades de Biologia Experimental. 26-29 August 1998; Caxambu.

9. Collares EF, Vinagre AM. Evidence of the effect of dipyrone on the central nervous system as a determinant of delayed gastric emptying observed in rats after its administration. Braz $J$ Med Biol Res 2003; 36: 1375-1382.

10. Collares EF, Vinagre AM. Effect of the GABAB agonist baclofen on dipyrone-induced delayed gastric emptying in rats. Braz J Med Biol Res 2005; 38: 99-104.

11. Takanaka A, Onoda K, Kainuma E, Lienard F, Omori Y. Effect of phenylpyrazolone derivatives on gastric emptying rate and drug absorption in rats. Jpn J Pharmacol 1973; 23: 745-747.

12. Bucaretchi F, Collares EF. Effect of Phoneutria nigriventer spider venom on gastric emptying in rats. Braz J Med Biol Res 1996; 29: 205-211.

13. St. Peter JV, Awni WM. Quantifying hepatic function in the presence of liver disease with phenazone (antipyrine) and its metabolites. Clin
Pharmacokinet 1991; 20: 50-65.

14. Loft S. Metronidazole and antipyrine as probes for the study of foreign compound metabolism. Pharmacol Toxicol 1990; 66 (Suppl 6): 1-31.

15. Pautet F, Barret R, Daudon M, Mathian B. Metabolism of antipyrine in man. Pathol Biol 1985; 33: 777-780.

16. Camilleri M, Malagelada JR. Gastric motility in disease. In: Akkermans LMA, Johnson AG, Read NW (Editors), Gastric and gastroduodenal motility. New York: Praeger; 1984. p 201-232.

17. McCann MJ, Rogers RC. Impact of antral mechanoreceptor activation on the vago-vagal reflex in the rat: functional zonation of responses. J Physiol 1992; 453: 401-411.

18. Raybould HE, Lloyd KC. Integration of postprandial function in the proximal gastrointestinal tract. Role of CCK and sensory pathways. Ann N Y Acad Sci 1994; 713: 143-156.

19. Bowery NG. GABAB receptor pharmacology. Annu Rev Pharmacol Toxicol 1993; 33: 109-147.

20. Couve A, Moss SJ, Pangalos MN. GABAB receptors: a new paradigm in G protein signaling. Mol Cell Neurosci 2000; 16: 296-312.

21. Sivarao DV, Krowicki ZK, Hornby PJ. Role of GABAA receptors in rat hindbrain nuclei controlling gastric motor function. Neurogastroenterol Motil 1998; 10: 305-313.

22. Greenwood-Van MB, Barron KW. Tonic GABA(A) receptor-mediated neurotransmission in the dorsal vagal complex regulates intestinal motility in rats. Eur J Pharmacol 1998; 346: 197-202.

23. Brooks PA, Glaum SR, Miller RJ, Spyer KM. The actions of baclofen on neurones and synaptic transmission in the nucleus tractus solitarii of the rat in vitro. J Physiol 1992; 457: 115-129.

24. Bertolino M, Kellar KJ, Vicini S, Gillis RA. Nicotinic receptor mediates spontaneous GABA release in the rat dorsal motor nucleus of the vagus. Neuroscience 1997; 79: 671-681.

25. Yuan CS, Liu D, Attele AS. GABAergic effects on nucleus tractus solitarius neurons receiving gastric vagal inputs. J Pharmacol Exp Ther 1998; 286: 736-741.

26. Andrews PL, Wood KL. Systemic baclofen stimulates gastric motility and secretion via a central action in the rat. Br J Pharmacol 1986; 89: 461-467. 